\title{
Molecular characterization of a Tax-2C protein variant identified in Brazilian subjects infected by HTLV-2C
}

\author{
Adele Caterino-de-Araujo ${ }^{1 *}$, Mariana Cavalheiro Magri ${ }^{2}$, Umberto Bertazzoni ${ }^{3}$, Maria Grazia Romanelli ${ }^{3}$ \\ From 16th International Conference on Human Retroviruses: HTLV and Related Viruses \\ Montreal, Canada. 26-30 June 2013
}

Although the etiologic difference in pathogenic properties of HTLV-1 and HTLV-2 still remains unclear, it has been suggested that it could be attributed to the differential structure and activities of their transactivating Tax proteins. Tax-1 and Tax-2, although having $85 \%$ amino acid (aa) similarity, present phenotypic differences consistent with a more robust transformation capacity of Tax-1. Interestingly, the HTLV-2C Brazilian variant present in Amerindians and in IDU from urban areas is genotypically close to HTLV-2A but Tax-2C possesses an additional $25 \mathrm{aa}$ in the C-terminal region similar to that of Tax-2B. We have already demonstrated that Tax-1 and Tax-2B have several common domains, but present differential cellular distribution. To add some information concerning the structure and site domains present in Tax-2C we conducted the present study. We have obtained the Tax-2C sequence from 25 different HTLV-2C subjects and analyzed the aminoacid homology between Tax-2B and Tax$2 \mathrm{C}$ variants. We found that they differ for amino acidic substitutions in eleven different positions that may affect cellular localization or post-translational modification. Studies on phenotypic properties and cellular localization of Tax-2C are in progress. Support: MCT/CNPq \# 303545/2012-7, CAPES, IAL \# 49D/2010), Brazil.

\section{Authors' details}

'Centro de Imunologia, Instituto Adolfo Lutz, Secretaria de Estado da Saúde de São Paulo, São Paulo, SP., Brasil. ${ }^{2}$ Laboratório de Investigações Médicas em Hepatologia por Vírus (LIM-47), Faculdade de Medicina, Universidade de São Paulo, São Paulo, SP., Brasil. ${ }^{3}$ Department of Life and Reproduction Sciences, Section of Biology and Genetics, University of Verona, Verona, Italy.

\footnotetext{
* Correspondence: caterino@usp.br

'Centro de Imunologia, Instituto Adolfo Lutz, Secretaria de Estado da Saúde de São Paulo, São Paulo, SP., Brasil

Full list of author information is available at the end of the article
}

Published: 7 January 2014

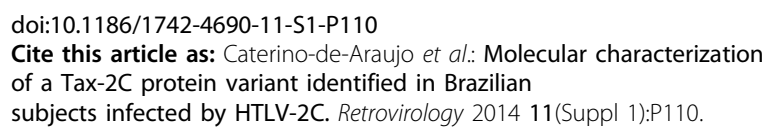

Cite this article as: Caterino-de-Araujo et al:: Molecular characterization of a Tax-2C protein variant identified in Brazilian subjects infected by HTLV-2C. Retrovirology 2014 11(Suppl 1):P110.

Submit your next manuscript to BioMed Central and take full advantage of:

- Convenient online submission

- Thorough peer review

- No space constraints or color figure charges

- Immediate publication on acceptance

- Inclusion in PubMed, CAS, Scopus and Google Scholar

- Research which is freely available for redistribution

Submit your manuscript at www.biomedcentral.com/submit
() Biomed Central 